\title{
Development of Haemophilia Treatment in the Eastern Part of Germany over the Last Decade in the Kompetenznetz Hämorrhagische Diathese Ost (KHDO)
}

\section{Entwicklung der Hämophiliebehandlung im Osten Deutschlands in den letzten 10 Jahren - eine Untersuchung des Kompetenznetz Hämorrhagische Diathese Ost (KHDO)}

\author{
Rebecca Mahn ${ }^{1}$ Kristina Schilling ${ }^{2}$ Robert Klamroth ${ }^{3}$ Karim Kentouche ${ }^{4}$ Volker Aumann ${ }^{5}$ \\ Lars Fischer $^{6}$ Susanne Holzhauer ${ }^{7}$ Harry Sirb $^{8}$ Ute Scholz ${ }^{9}$ Karolin Trautmann ${ }^{10}$ \\ Ines Halm-Heinrich ${ }^{11}$ Beate Krammer-Steiner ${ }^{12}$ Jürgen Koscielny ${ }^{13}$ Ute Kreibich ${ }^{14}$ \\ Antje Pietrzak-Büttner ${ }^{15}$ Matthias Tregel ${ }^{16}$ Ralf Knöfler ${ }^{17}$ Christian Pfrepper $^{1}$ \\ and the Kompetenznetzwerk Hämorrhagische Diathese Ost
}

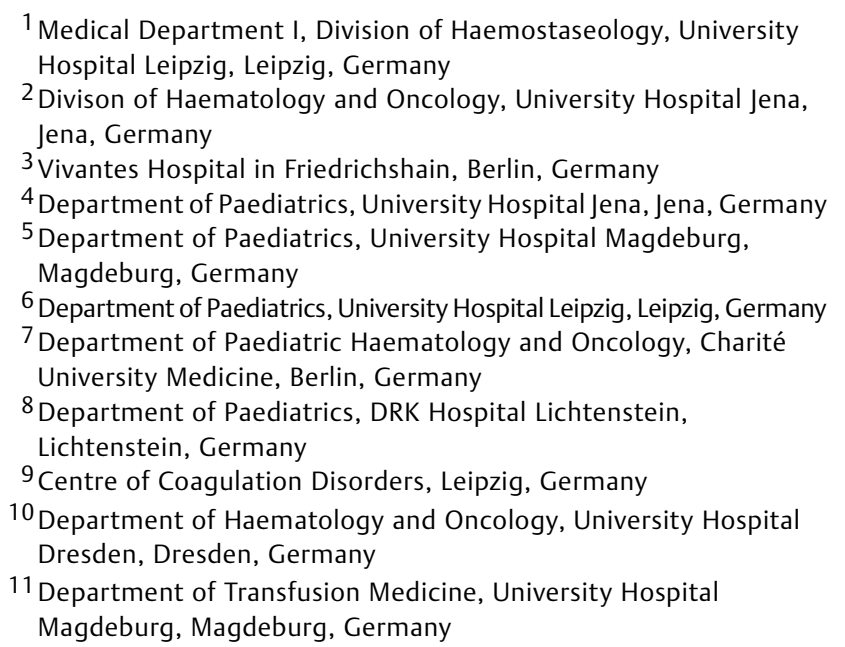

Address for correspondence Christian Pfrepper, Medical Department I, Division of Haemostaseology, University Hospital Leipzig, Liebigstr. 20, 04103 Leipzig, Germany

(e-mail: christian.pfrepper@medizin.uni-leipzig.de).
${ }^{12}$ Department of Haematology and Oncology, Rostock South City Medical Centre, Rostock, Germany
${ }^{13}$ Haemophilia Centre (EHCCC) with outpatient ambulance in the ambulance service (AGZ) of the Charité, Charité Universitätsmedizin Berlin, Germany
${ }^{14}$ Haemophilia Ambulance, Heinrich Braun Hospital, Zwickau, Germany
15 Paediatric Clinic, SRH Hospital Suhl, Suhl, Germany
16 Ruppin General Hospital, Institute of Laboratory Medicine, Brandenburg Medical School, Neuruppin, Germany
${ }^{17}$ Department of Paediatric Haematology and Oncology, University Hospital Dresden, Dresden, Germany
Abstract
Keywords
- haemophilia
- epidemiologic data
- factor consumption
- hepatitis C

Introduction In 2005 the Kompetenznetz Hämorrhagische Diathese Ost published epidemiologic data about patients with haemophilia $A(H A)$ and haemophilia $B(H B)$ in the eastern part of Germany. This study provides data about the development of treatment in these patients over the past 10 years.

Methods Data from 12 haemophilia centres in eastern Germany were retrospectively collected for the year 2015 from patients' records.
Remark: Our study includes data of 42 patients that were included in the publication by Olivieri et al, Prevalence of Obesity in Young Patients with Severe Haemophilia and Its Potential Impact on Factor VIII Consumption in Germany. Hamostaseologie 2019. doi10.1055/s-0039-1677874.

received

March 8, 2019

accepted after revision

September 26, 2019 (c) 2020 Georg Thieme Verlag KG Stuttgart · New York
DOI https://doi.org/

10.1055/s-0039-3399493. ISSN 0720-9355. 


\section{Zusammenfassung}

\section{Schlüsselwörter}

- Hämophilie

- Epidemiologie

- Faktorenverbrauch

- Hepatitis C
Results We evaluated 413 patients ( 115 children, 298 adults) with HA or HB. A total of 286 patients $(69.2 \%)$ had severe haemophilia (patients with severe haemophilia, PWSH). Compared with 2005, the proportion PWSH on prophylaxis increased from $90 \%$ to $98.8 \%$ in children and from $64 \%$ to $80.2 \%$ in adults. The use of plasma-derived factor concentrates decreased from $>70 \%$ to $55.3 \%$ in children and to $55.1 \%$ in adults. Mean annual factor consumption in PWSH without inhibitor was higher in 2015 compared with 2005 (children with HA: 151,489 vs. 98,894; adults with HA: 217,151 vs. 151,394; children with HB: 105,200 vs. 64,256 ; adults with HB: 159,185 vs. 85,295 ). Median annualized bleeding (annualized bleeding rate, ABR) and joint bleeding rates (annualized joint bleeding rate, AJBR) in 2015 were 2 and 0 in children and 3 and 0 in adults, respectively. In 2015 only one child (1.2\%) but 101 (53.2\%) adults with severe haemophilia were anti-hepatitis C virus (anti-HCV) positive. The rate of anti-HCV positive patients with active hepatitis C dropped from $63.8 \%$ to $12.9 \%$.

Conclusions Within the last decade more patients with severe haemophilia were switched to a prophylactic regimen going along with a moderate increase in factor consumption achieving a low ABR and AJBR.

Einleitung Im Jahr 2005 hat das Kompetenznetz Hämorrhagische Diathese Ost epidemiologische Daten über Patienten im Osten Deutschlands mit Hämophilie A $(\mathrm{HA})$ und $B(\mathrm{HB})$ publiziert. Diese Studie liefert Daten über die Entwicklung der Hämophiliebehandlung bei diesen Patienten in den letzten 10 Jahren.

Methoden Daten von 12 Hämophiliezentren im Osten Deutschlands aus dem Jahr 2015 wurden retrospektiv aus den Patientenakten ausgewertet.

Ergebnisse Wir untersuchten 413 Patienten (115 Kinder, 298 Erwachsene) mit HA oder HB. 286 Patienten (69,2\%) hatten eine schwere Hämophilie (PMSH). Im Vergleich zu 2005 ist der Anteil der PMSH mit Prophylaxe bei den Kindern von 90\% auf 98.8\% und bei den Erwachsenen von $64 \%$ auf $80,2 \%$ angestiegen. Der Verbrauch von plasmatischen Faktorenkonzentraten ist von $>70 \%$ auf $55,3 \%$ bei Kindern und $55,1 \%$ bei Erwachsenen gesunken. Der mittlere Faktorenverbrauch bei PMSH ohne Hemmkörper war 2015 höher als 2005 (Kinder mit HA 151.489 versus 98.894, Erwachsene mit HA 217.151 versus 151.394, Kinder mit HB 105.200 versus 64.256, Erwachsenen mit HB 159.185 versus 85.295$)$. Die mediane jährliche Blutungsrate und Gelenkblutungsrate in 2015 war 2 bzw. 0 bei Kindern und 3 bzw. 0 bei Erwachsenen. Im Jahr 2015 war lediglich ein Kind (1,2\%) aber 101 (53,2\%) Erwachsene mit schwerer Hämophilie antiHCV positiv. Der Anteil der anti-HCV-positiven Erwachsenen mit aktiver Hepatitis C fiel von $63,8 \%$ auf $12,9 \%$.

Zusammenfassung In den letzten 10 Jahren wurden mehr Patienten auf eine prophylaktische Behandlung umgestellt. Dies geht mit einem moderaten Anstieg des Verbrauchs an Faktorenkonzentraten einher, resultiert aber in einer niedrigen Blutungsrate.

\section{Introduction}

Haemophilia A and B (HA and $\mathrm{HB}$ ) are rare hereditary bleeding disorders characterized by the deficiency or complete absence of clotting factor VIII (FVIII) or IX (FIX) leading to spontaneous bleeds into muscles and joints. The severity of the disease is determined by the residual factor activity, ${ }^{1}$ but the clinical manifestation may vary. ${ }^{2}$ For patients with severe haemophilia (PWSHs), standard of care is prophylac- tic substitution of factor concentrates as prophylaxis reduces joint bleedings and improves joint status. ${ }^{3-5}$ Beside this, it is known that in children early prophylaxis results in a better joint status. ${ }^{6}$ In addition, patients still benefit from prophylaxis when it is started later in life, ${ }^{5}$ making prophylaxis the standard of care in all PWSHs. There are two approaches of prophylaxis with a fixed regimen depending on body weight (BW) and tailored regimens taking into account bleeding phenotype and pharmacokinetic properties. 
As prophylaxis is nowadays considered standard of care in haemophilia treatment, changes in treatment strategies and factor consumption over time are of special interest.

In Germany, the annual factor consumption of patients with haemophilia (PWHs) is usually reported to the Paul Ehrlich Institute as a collective report. Some clinicians also report individual data to the German Haemophilia Registry, but in 2015 only in $38.6 \%$ of all PWSHs individual data were announced. ${ }^{7}$ As a result there is a lack of comprehensive data reflecting changes in factor consumption and different treatment strategies in Germany over time.

The Kompetenznetzwerk Hämorrhagische Diathese Ost (KHDO) is an association of clinicians dedicated to "supporting clinical and scientific research in the field of haemophilia and severe coagulation disorders and improving clinical care for these patients" in the eastern part of Germany. The KHDO published epidemiologic data based on the reports submitted to the Paul Ehrlich Institute regarding treatment strategies, factor consumption and infections in $\mathrm{PWHs}$ in eastern Germany in 2005. ${ }^{8}$

The aim of this study was to collect current epidemiologic data including patient characteristics, bleeding rates, weight classification and infectious diseases. Comparing these data with our previously published data from 2005, we intended to document changes in haemophilia treatment over the last decade in eastern Germany.

\section{Methods}

Retrospective data of the year 2015 from patients with HA and HB were provided from 12 haemophilia centres in eastern Germany. Data were collected from patient diaries and medical records regarding age, height, $\mathrm{BW}$, blood group, dosing regimen, factor consumption, documented bleeds and inhibitory antibodies. Severity of haemophilia, bleeding events and inhibitor status were documented according to the current International Society of Thrombosis and Haemostasis (ISTH) guideline. ${ }^{9}$ All patients with $\mathrm{HA}$ or $\mathrm{HB}$ who had a complete patient diary for 2015 with documented bleeds and factor consumption were eligible. In addition, we included three patients with available data on virology but without completed patient diary. Data were analysed in the haemophilia centres and the treating physicians were consulted for clarification in case of conspicuities.

Bleeds were measured as documented by the patients and treating physicians. As annualized bleeding rate (ABR) all documented bleeds were summarized, while the annualized joint bleeding rate (AJBR) only refers to documented joint bleeds. In addition, major bleedings were defined as non-joint bleedings that were life-threatening or led to hospital admission or required transfusion of red blood cells. As minor bleedings all other haemorrhages with documented bleeding sites were counted. Additional substitutions without further information in patient diaries or medical records and bleedings without specified bleeding site were counted as unclear substitutions and summarized as bleedings in the total ABR.

In addition, results from human immunodeficiency virus (HIV) antibodies, anti-HBs, HB-antigen, anti-hepatitis C virus
(anti-HCV) and HCV-polymerised chain reaction (PCR) measurements were obtained in patients with available data.

Body mass index (BMI) was calculated using the formula: BMI $=$ weight $[\mathrm{kg}] /$ size $\left[\mathrm{m}^{2}\right]=\left[\mathrm{kg} / \mathrm{m}^{2}\right]$. For adults $(\geq 18$ years $)$, BMI was classified according to the World Health Organization guideline. Overweight is therefore defined as BMI of 25 to $29 \mathrm{~kg} / \mathrm{m}^{2}$ and obesity as a BMI of $\geq 30 \mathrm{~kg} / \mathrm{m}^{2} .{ }^{10}$ In children $(<18$ years), the percentile curves according to Kromeyer-Hauschild were used for classification. Overweight is here referred to as BMI between 90th and 97th percentiles, obesity between 97th and 99.5th percentiles and extreme obesity as $\geq 99.5$ th percentiles. ${ }^{11,12}$

For the calculation of factor consumption, 5 patients ( 2 children, 3 adults) with inhibitory FVIII or FIX antibodies and 2 patients ( 1 child, 1 adult) with a negative Bethesda test but a remaining shortened half-life after immune tolerance induction were excluded.

\section{Statistics}

For statistical analysis, values were calculated for normal distribution using the method of Shapiro-Wilk and Kolmogorov-Smirnov. As values were not normally distributed, statistical significance was determined by applying the Mann-Whitney U test. A $p$-value $<0.05$ was rated as statistically significant. Data from 2015 were given as mean when they were compared with 2005 because data from 2005 were only available as mean. Other data from 2015 are given as median with an interquartile range (IQR; 25th and 75th percentiles). Statistical analysis was performed using SPSS version 22.

This study reports data of 42 patients that were included in the publication by Olivieri et al.. ${ }^{13}$

\section{Results}

We screened 417 patients and excluded four patients due to inconsistent data in patients' diaries and medical records. In total, we collected data of 413 patients ( 115 children and 298 adults) with HA or HB. The median age in the whole cohort was 32 years, in the paediatric group 9 years and in the adult cohort 44 years. Most patients had severe haemophilia (83 children [72.2\%] and 203 adults [68.1\%]). In total, 96 (83.5\%) children and 249 (83.6\%) adults suffered from HA. Patients' characteristics are summarized in -Table 1.

\section{Therapeutic Regimen}

Almost all children (98.8\%) with severe haemophilia were treated prophylactically. Because of the young age, one infant born in 2015 with severe haemophilia had an ondemand treatment with $500 \mathrm{IU}$. He started prophylaxis in early 2016. In the adult cohort, 162 (80.2\%) PWSHs had a prophylactic treatment in 2015. In patients with moderate haemophilia, more children had a prophylaxis compared with adults (54.5 vs. $18.4 \%$ ). Five $(71.4 \%)$ children with moderate HA but only one (25\%) child with moderate HB were on prophylaxis. In seven (31.8\%) adults with moderate HA but not in adults with moderate $\mathrm{HB}$, a prophylactic factor substitution was prescribed. 
Table 1 Characteristics of 413 patients included in the study

\begin{tabular}{|c|c|c|c|c|}
\hline & & & Children & Adults \\
\hline Age $(y)$ & & $n$; median (range) & $115 ; 9(1-17)$ & 298; $43.5(18-83)$ \\
\hline Body weight (kg) & & $n$; median (range) & $115 ; 30(8-111)$ & $292 ; 81.1(46-130)$ \\
\hline BMI $\left(\mathrm{kg} / \mathrm{m}^{2}\right)$ & & $n$; median (range) & $112 ; 17.6(6.7-34)$ & $281 ; 26(17.9-42.6)$ \\
\hline \multirow[t]{3}{*}{ Haemophilia A } & Severe & $n,(\%)$ & $74(64.4 \%)$ & 176 (59.0\%) \\
\hline & Moderate & $n,(\%)$ & 7 (6.1\%) & $22(7.4 \%)$ \\
\hline & Mild & $n,(\%)$ & $15(13 \%)$ & $51(17.1 \%)$ \\
\hline \multirow[t]{3}{*}{ Haemophilia B } & Severe & $n,(\%)$ & $9(7.8 \%)$ & $27(9.1 \%)$ \\
\hline & Moderate & $n,(\%)$ & $4(3.5 \%)$ & $16(5.4 \%)$ \\
\hline & Mild & $n,(\%)$ & $6(5.2 \%)$ & $6(2 \%)$ \\
\hline \multirow[t]{2}{*}{ Therapeutic regimen } & Prophylaxis & $n,(\%)$ & $90(78.3 \%)$ & $171(57.4 \%)$ \\
\hline & On-demand & $n,(\%)$ & $25(21.7 \%)$ & $127(42.6 \%)$ \\
\hline \multirow[t]{2}{*}{ Inhibitor status } & Active inhibitor & $n,(\%)$ & $2(1.7 \%)$ & $3(1 \%)$ \\
\hline & History of an inhibitor & $n,(\%)$ & $10(8.7 \%)$ & $9(3 \%)$ \\
\hline
\end{tabular}

Abbreviation: BMI, body mass index.

Note: The numbers are given for patients with available data.

In 2005 only $90 \%$ of the children with severe haemophilia and $64 \%$ of the adults were on prophylaxis. ${ }^{8}$ Change in therapeutic regimen is shown in - Fig. 1.

In total, $67.2 \%$ of children with severe HA on prophylaxis were treated with doses ranging from 20 to 39 IU $/ \mathrm{kg}$ BW FVIII or FIX, while $79.4 \%$ of the adults with severe HA on prophylaxis were treated with $\leq 29 \mathrm{IU} / \mathrm{kg}$ BW FVIII or FIX. In addition, more children had a dose $\geq 40 \mathrm{IU} / \mathrm{kg}$ BW compared to adults (HA 11.5 vs. 4.4\%; HB 22.2 vs. 0\%). Prophylaxis was administered in patients with severe HA three times per week in 51 (83.6\%) children but only in 76 (55.9\%) adults. Prophylaxis regimens in children and adults are summarized in -Tables 2 and 3.

In 2015 a total of 48 (42.1\%) children and 124 (41.6\%) adults were treated with recombinant factor concentrates. In the group of PWSHs, more adults $(n=106 ; 52.5 \%)$ than children $(n=37 ; 44.6 \%)$ were treated with a recombinant factor. In contrast, in 2005 only $19 \%$ of the children and $24 \%$ of the adults were on recombinant factor concentrates (-Fig. 2).

\section{Factor Consumption}

Median annual factor consumption in PWSHs was 125,400 $(84,438-202,000)$ IU in children $(n=80)$ and $183,500(94,500-$ $279,000)$ IU in adults $(n=196)$. Children with severe HA had a trend toward higher median factor consumption compared with children with severe HB $(129,000[90,000-209,000]$ vs. $80,400[68,700-138,300] \mathrm{IU} ; p=0.074)$, reaching significance in adult patients $(186,000[116,750-289,000]$ vs. 116,400 $[43,200-247,000] \mathrm{IU} ; p=0.047)$. When factor consumption was adjusted to BW, children with severe HA had a significantly higher consumption than children with severe $\mathrm{HB}(4,700$ [2,902-6,272] vs. $2,062[1,468-4,075] \mathrm{IU} / \mathrm{kg} ; p<0.01)$. This difference was also seen in adult patients $(2,288$ [1,503-3,645] vs. 1,940 [575-2,942] IU/kg; $p=0.040)$. Remarkably, children
2005

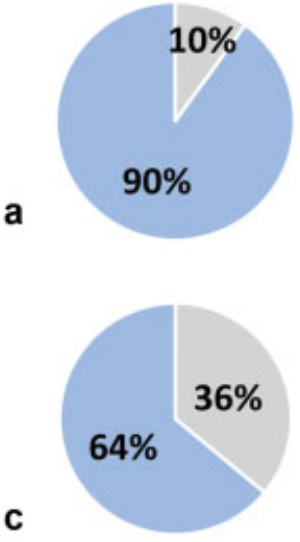

2015

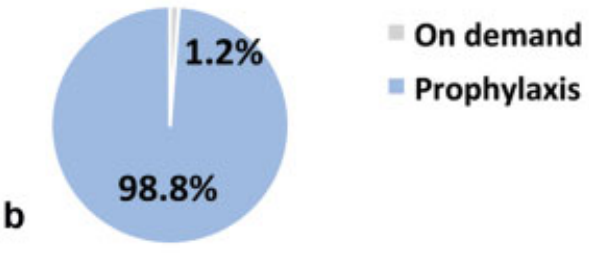

$19.8 \%$

$80.2 \%$

Fig. 1 Therapeutic regimen in patients with severe haemophilia: (a) children in 2005; (b) children in 2015; (c) adults in 2005 ; (d) adults in 2015. 
Table 2 Prophylaxis regimens in 70 children with severe haemophilia without inhibitors

\begin{tabular}{|c|c|c|c|c|c|c|c|c|}
\hline \multirow[t]{2}{*}{ Children } & \multicolumn{4}{|c|}{ Haemophilia A, $n=61$} & \multicolumn{4}{|c|}{ Haemophilia B, $n=9$} \\
\hline & $\leq 19 \mathrm{lU} / \mathrm{kg}$ & $20-29 \mathrm{lU} / \mathrm{kg}$ & $30-39 \mathrm{lU} / \mathrm{kg}$ & $\geq 40 \mathrm{lU} / \mathrm{kg}$ & $\leq 19 \mathrm{lU} / \mathrm{kg}$ & $20-29 \mathrm{IU} / \mathrm{kg}$ & $30-39 \mathrm{lU} / \mathrm{kg}$ & $\begin{array}{l}\geq 40 \\
1 \mathrm{UU} / \mathrm{kg}\end{array}$ \\
\hline $1 \times / d$ & 0 & 0 & 0 & 0 & 0 & 0 & 0 & 0 \\
\hline $3 \times /$ wk & 10 & 18 & 17 & 6 & 0 & 0 & 0 & 0 \\
\hline $2 \times / \mathrm{wk}$ & 3 & 3 & 2 & 0 & 0 & 2 & 2 & 1 \\
\hline $1 \times / \mathrm{wk}$ & 0 & 0 & 1 & 1 & 0 & 2 & 1 & 1 \\
\hline Total & $\begin{array}{l}13 \\
(21.3 \%)\end{array}$ & $\begin{array}{l}21 \\
(34.4 \%)\end{array}$ & $\begin{array}{l}20 \\
(32.8 \%)\end{array}$ & $\begin{array}{l}7 \\
(11.5 \%)\end{array}$ & $\begin{array}{l}0 \\
(0.0 \%)\end{array}$ & $\begin{array}{l}4 \\
(44.5 \%)\end{array}$ & $\begin{array}{l}3 \\
(33.3 \%)\end{array}$ & $\begin{array}{l}2 \\
(22.2 \%)\end{array}$ \\
\hline
\end{tabular}

Table 3 Prophylaxis regimens in 153 adults with severe haemophilia without inhibitors

\begin{tabular}{|c|c|c|c|c|c|c|c|c|}
\hline Adults & Haemophi & $A, n=136$ & & & Haemophi & B, $n=17$ & & \\
\hline & $\leq 19 \mathrm{IU} / \mathrm{kg}$ & $20-29 \mathrm{IU} / \mathrm{kg}$ & $30-39 \mathrm{IU} / \mathrm{kg}$ & $\geq 40 \mathrm{IU} / \mathrm{kg}$ & $\leq 19 \mathrm{IU} / \mathrm{kg}$ & $20-29 \mathrm{IU} / \mathrm{kg}$ & $30-39 \mathrm{lU} / \mathrm{kg}$ & $\geq 40 \mathrm{IU} / \mathrm{kg}$ \\
\hline $1 \times / d$ & 0 & 0 & 0 & 1 & 1 & 0 & 0 & 0 \\
\hline $3 \times / w k$ & 35 & 26 & 12 & 3 & 2 & 1 & 0 & 0 \\
\hline $2 \times / w k$ & 12 & 25 & 9 & 2 & 4 & 4 & 0 & 0 \\
\hline $1 \times / w k$ & 5 & 5 & 1 & 0 & 2 & 2 & 1 & 0 \\
\hline Total & $\begin{array}{l}52 \\
(38.2 \%)\end{array}$ & $\begin{array}{l}56 \\
(41.2 \%)\end{array}$ & $\begin{array}{l}22 \\
(16.2 \%)\end{array}$ & $\begin{array}{l}6 \\
(4.4 \%)\end{array}$ & $\begin{array}{l}9 \\
(52.6 \%)\end{array}$ & $\begin{array}{l}8 \\
(42.1 \%)\end{array}$ & $\begin{array}{l}1 \\
(5.3 \%)\end{array}$ & $\begin{array}{l}0 \\
(0.0 \%)\end{array}$ \\
\hline
\end{tabular}

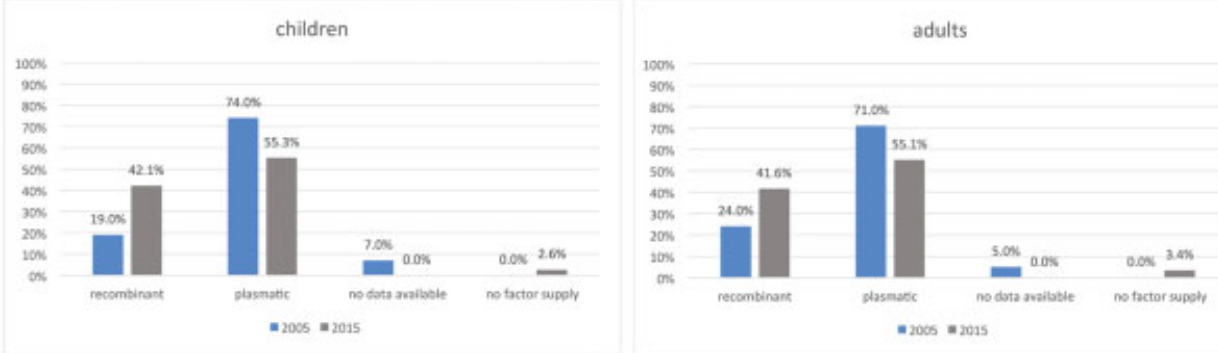

Fig. 2 Use of factor concentrates in patients with haemophilia in 2005 and 2015.

with moderate HA had a median annual factor consumption of 144,000 (9,000-195,000) IU while adults with moderate HA used only $34,500(6,750-161,250)$ IU $(p=0.53)$. Patients with moderate HA used significantly more factor concentrates than patients with moderate HB (children: 144,000 [9,000$195,000]$ vs. $7,800[1,650-41,625]$ IU, $p<0.01$; adults: $34,500[6,750-161,250]$ vs. $1,200[0-6,000]$ IU, $p<0.01)$.

In relation to their BW, children with severe haemophilia used more factor concentrates than adults. Median annual consumption in children with severe HA was 4,700 [2,902-6,272] IU/kg and for adults 2,288 [1,503-3,645] IU/ $\mathrm{kg}(p<0.01)$. This difference was still significant when patients with on-demand therapy were excluded $(4,727$ [3,042-6,281] vs. $2,529[1,741-3,848] \mathrm{IU} / \mathrm{kg}, p<0.01)$. In HB patients no statistical significance was observed $(2,062$ $[1,468-4,075]$ vs. $1,940[575-2,942] \mathrm{IU} / \mathrm{kg}, p=0.607)$

Compared with 2005, mean factor consumption increased in children with severe HA and HB by around 50,000 IU and adults by around 65,000 IU. We were not able to conduct adequate and detailed statistical comparison between our results and those for 2005 because we did not have the individual factor consumption for patients in 2005. Mean factor consumption is summarized in -Table 4.

\section{Bleeding Rates}

Children with severe haemophilia on prophylaxis had a mean ABR of 4.2 (median 2, IQR 1-6) and a mean documented AJBR of 1.1 (median 0, IQR 0-1). Adults with severe haemophilia on prophylaxis had a mean ABR of 5.1 (median 3, IQR 1-7) and a mean documented AJBR of 1.9 (median 0 , IQR $0-2.8)$. Major bleeds were rare in adults $(n=8$, mean 0.05 ) and there was no documented major bleeding in children with severe haemophilia. However, substitutions for unclear reasons were frequent: in children 100 and in adults 398 substitutions of unknown reason were documented. In PWSHs, children and adults had 82 and 316 
Table 4 Mean annual factor consumption in patients with haemophilia in 2005 and 2015

\begin{tabular}{|l|l|l|l|l|l|}
\hline & & \multicolumn{3}{|l|}{ Children } & \multicolumn{2}{l|}{ Adults } \\
\hline & & $\mathbf{2 0 1 5}$ & $\mathbf{2 0 0 5}$ & $\mathbf{2 0 1 5}$ & $\mathbf{2 0 0 5}$ \\
\hline \multirow{4}{*}{$\begin{array}{l}\text { Haemophilia } \\
\text { A }\end{array}$} & Severe & 151,489 & 98,894 & 217,151 & 151,394 \\
& & $n=71$ & $n=81$ & $n=169$ & $n=246$ \\
\cline { 2 - 6 } & Moderate & 106,429 & 65,486 & 75,682 & 49,603 \\
& & $n=7$ & $n=29$ & $n=22$ & $n=96$ \\
\cline { 2 - 6 } & Mild & 16,200 & 26,524 & 13,804 & 3,631 \\
& & $n=15$ & $n=60$ & $n=51$ & $n=158$ \\
\hline Haemophilia & Severe & 105,200 & 64,256 & 159,185 & 85,295 \\
& & $n=9$ & $n=20$ & $n=27$ & $n=51$ \\
\cline { 2 - 6 } & Moderate & 17,025 & 22,967 & 3,520 & 13,900 \\
& & $n=4$ & $n=3$ & $n=15$ & $n=30$ \\
\cline { 2 - 6 } & Mild & 167 & 8,500 & 9,200 & 6,393 \\
& & $n=6$ & $n=8$ & $n=5$ & $n=46$ \\
\hline
\end{tabular}

unclear substitutions, respectively. Bleeding rates in PWSHs on prophylaxis are displayed in - Table 5.

Mean ABR in adult PWSHs on prophylaxis was 5.1 versus 10.2 in patients with on-demand therapy $(p=0.19)$. Mean AJBR was significantly lower in patients on prophylaxis (1.9 vs. $5.5, p<0.01)$.

\section{Influence of Body Weight and BMI on Factor Consumption and Bleeding Rates}

According to the classification of Kromeyer-Hauschild in 112 children with available data, 85 (75\%) had a normal BW, 7 (6.2\%) were overweight, 11 (9.7\%) underweight and $9(8.0 \%)$ patients were obese. Children with severe haemophilia showed the same distribution (underweight $10 \%$, normal weight $73.3 \%$, overweight $6.3 \%$, obese $10 \%$ ).

In 281 adult patients with available data, 118 (42.0\%) had a normal BW, 96 (34.2\%) were overweight, 47 (16.7\%) had obesity grade 1 and 15 (5.4\%) obesity grade 2 or 3, while only $5(1.8 \%)$ were underweight, showing the same distribution in adults with severe haemophilia.
Overweight and obese children with severe haemophilia without inhibitors on prophylaxis had lower factor consumption per kg BW than children with normal weight or underweight. In adults this difference did not reach statistical significance. In addition, bleeding rates in children and adults with and without overweight were not statistically different ( $>$ Table 6 ).

\section{Inhibitors}

Among the 115 children, only two (1.7\%) had an active inhibitor against FVIII, revealed by a positive Bethesda test at the time of the survey. Both had an inhibitor titer $>5$ Bethesda units (BU). Another 10 children (8.7\%) had a history of an inhibitor but a negative Bethesda test at the time of our survey. The historical titer was $>5 \mathrm{BU}$ in five (50\%) children.

Among the 298 adults, three (1.0\%) had an active inhibitor (one low titer and two high titers). Another 8 patients had a history of an inhibitor ( 2 low titer, 3 high titer and 3 with unknown titer).

\section{Virology}

All children with available data were negative for HIV, HCVPCR and HBs-antigen. There was one anti-HCV-positive child and another anti-HBc positive child. Of the 112 children with available laboratory findings or vaccination records, 105 (93.8\%) had a detectable anti-HBs titer. Seven adults with haemophilia (2.3\%) and six adults with severe haemophilia (3.2\%) were carriers of the HBs-antigen. The prevalence of anti-HBc-positive patients was $34.2 \%$ in the whole cohort of adult patients and $47.3 \%$ in adults with severe haemophilia. In the whole adult population, we found 112 (37.6\%) anti-HCV-positive patients, most of them had severe haemophilia ( $n=101 ; 53.2 \%)$. However, only 13 (6.8\%) PWSHs were HCV-PCR positive.

In 2005, 149 patients were documented as being anti-HCV positive. Of these 149 patients, 95 (63.8\%) were HCV-PCR

Table 5 Bleeding rates in patients with severe haemophilia on prophylaxis without inhibitor

\begin{tabular}{|c|c|c|c|c|c|}
\hline & & $\begin{array}{l}\text { Total number of documented } \\
\text { bleeds/substitutions, } n\end{array}$ & Mean & Median & IQR \\
\hline \multirow[t]{5}{*}{ Children, $n=79$} & $A B R$ & 331 & 4.2 & 2 & $1-6$ \\
\hline & AJBR & 75 & 1.1 & 0 & $0-1$ \\
\hline & Major bleeds & 0 & 0 & 0 & $0-0$ \\
\hline & Minor bleeds & 174 & 2.2 & 1 & $0-3$ \\
\hline & $\begin{array}{l}\text { Unclear } \\
\text { substitutions }\end{array}$ & 82 & 1.0 & 0 & $0-1$ \\
\hline \multirow[t]{5}{*}{ Adults, $n=148$} & $\mathrm{ABR}$ & 749 & 5.1 & 3 & $1-7$ \\
\hline & AJBR & 289 & 1.9 & 0 & $0-2.8$ \\
\hline & Major bleeds & 8 & 0.05 & 0 & $0-0$ \\
\hline & Minor bleeds & 136 & 0.92 & 0 & $0-1$ \\
\hline & $\begin{array}{l}\text { Unclear } \\
\text { substitutions }\end{array}$ & 316 & 2.2 & 0 & $0-2$ \\
\hline
\end{tabular}

Abbreviations: ABR, annualized bleeding rate; AJBR, annualized joint bleeding rate; IQR, interquartile range. 
Table 6 Factor consumption and bleeding rates in patients with severe haemophilia without inhibitors on prophylaxis according to body weight and BMI

\begin{tabular}{|c|c|c|c|c|c|c|c|}
\hline & & \multicolumn{3}{|l|}{ Children } & \multicolumn{3}{|l|}{ Adults } \\
\hline & & $\leq$ Normal weight & $\geq$ Overweight & $p$ & $\mathrm{BMI}<30$ & $\mathrm{BMI} \geq 30$ & $p$ \\
\hline $\begin{array}{l}\text { Annual } \\
\text { factor } \\
\text { use (IU) }\end{array}$ & $\begin{array}{l}\text { Median } \\
\text { (Q25-Q75) }\end{array}$ & $\begin{array}{l}124,800 \\
(88,500-211,000) \\
n=65\end{array}$ & $\begin{array}{l}140,750 \\
(103,350-171,625) \\
n=12\end{array}$ & 0.844 & $\begin{array}{l}197,200 \\
(144,000-299,750) \\
n=122\end{array}$ & $\begin{array}{l}245,750 \\
(201,250-337,750) \\
n=28\end{array}$ & 0.111 \\
\hline $\begin{array}{l}\text { Annual } \\
\text { factor } \\
\text { use } / \mathrm{kg} \text { BW } \\
(\mathrm{IU} / \mathrm{kg})\end{array}$ & $\begin{array}{l}\text { Median } \\
\text { (Q25--Q75) }\end{array}$ & $\begin{array}{l}4,755 \\
(3,365-6,123) \\
n=65\end{array}$ & $\begin{array}{l}2,242 \\
(2,034-4,384) \\
n=12\end{array}$ & 0.045 & $\begin{array}{l}2,543 \\
(1,730-3,927) \\
n=122\end{array}$ & $\begin{array}{l}2,284 \\
(1,721-3,112) \\
n=28\end{array}$ & 0.235 \\
\hline $\begin{array}{l}\text { Annual } \\
\text { factor } \\
\text { use/BMI } \\
\text { (IU/BMI) }\end{array}$ & $\begin{array}{l}\text { Median } \\
\text { (Q25-Q75) }\end{array}$ & $\begin{array}{l}8,102 \\
(5,553-11,572) \\
n=65\end{array}$ & $\begin{array}{l}5703 \\
(4,115-7,193) \\
n=12\end{array}$ & 0.074 & $\begin{array}{l}7,851 \\
(5,745-11,833) \\
n=121\end{array}$ & $\begin{array}{l}6,936 \\
(5,762-9,335) \\
n=28\end{array}$ & 0.125 \\
\hline$A B R$ & $\begin{array}{l}\text { Median } \\
\text { (Q25-Q75) }\end{array}$ & $\begin{array}{l}3(1-6) \\
n=65\end{array}$ & $\begin{array}{l}2(0-4) \\
n=12\end{array}$ & 0.269 & $\begin{array}{l}3(0.25-7) \\
n=114\end{array}$ & $\begin{array}{l}2(1-3.5) \\
\mathrm{n}=28\end{array}$ & 0.333 \\
\hline AJBR & $\begin{array}{l}\text { Median } \\
\text { (Q25-Q75) }\end{array}$ & $\begin{array}{l}0(0-1) \\
n=65\end{array}$ & $\begin{array}{l}0(0-0) \\
n=12\end{array}$ & 0.187 & $\begin{array}{l}0(0-3) \\
n=114\end{array}$ & $\begin{array}{l}0(0-1) \\
n=28\end{array}$ & 0.199 \\
\hline
\end{tabular}

Abbreviations: ABR, annualized bleeding rate; AJBR, annualized joint bleeding rate; BMI, body mass index; IQR, interquartile range.

positive. In 2015 this rate decreased to $12.9 \%$. Available data about virology are summarized in -Table 7 .

\section{Discussion}

The aim of this retrospective study was to demonstrate changes in haemophilia care in East Germany and to compare the data obtained in 2015 with those from the previous study of the KHDO one decade ago. ${ }^{8}$ We collected data from 413 PWHs from 12 haemophilia treatment centres in 2015 and evaluated them with regard to patients' characteristics, factor consumption, bleeding rates and infectious diseases.

We found a stronger adherence to the prophylactic regimen in 2015 compared with 2005. Almost all children and $80 \%$ of the adult PWSHs received prophylactic substitution. As a result, factor consumption increased within the last decade but still remains moderate. Other studies found the annual factor consumption in adults on prophylaxis to be
4,102 IU/kg BW (median) in severe $\mathrm{HA}^{5}$ and 4,945 IU/kg BW (mean) in severe HB. ${ }^{14}$ In our cohort adults with severe HA and $\mathrm{HB}$ on prophylaxis only used 2,288 IU/kg BW (median) and $1,845 \mathrm{IU} / \mathrm{kg}$ BW (mean), respectively.

The median annual, BW-related consumption in prophylactically treated children with severe HA was significantly higher compared with adults receiving prophylaxis $(4,727$ [3,042-6,281] vs. 2,529 [1,741-3,848] IU/ $\mathrm{kg}, p<0.01)$. Compared with 2005, mean factor consumption in 2015 increased in children with severe HA and HB by approximately 50,000 IU.

This moderate increase in factor consumption can be further explained with a change in treatment strategies in PWHs. As described in the literature and performed in many haemophilia centres, the treatment strategy has changed in the last decade from a regimen based on BW and fixed time intervals to a more personalized prophylactic regimen based on individual factor pharmacokinetics, trough levels and bleeding rates with the

Table 7 Prevalence of viral infections in children and adults with haemophilia

\begin{tabular}{|c|c|c|c|c|}
\hline & Children, $n$ (\%) & $\begin{array}{l}\text { Children with severe } \\
\text { haemophilia, } n(\%)\end{array}$ & Adults, $n(\%)$ & $\begin{array}{l}\text { Adults with severe } \\
\text { haemophilia, } n(\%)\end{array}$ \\
\hline HIV positive & $\begin{array}{l}0,(0 \%) \\
n=113\end{array}$ & $\begin{array}{l}0,(0 \%) \\
n=81\end{array}$ & $\begin{array}{l}9,(3 \%) \\
n=277\end{array}$ & $\begin{array}{l}5,(2.7 \%) \\
n=188\end{array}$ \\
\hline Anti-HCV positive & $\begin{array}{l}1,(0.9 \%) \\
n=113\end{array}$ & $\begin{array}{l}1,(1.2 \%) \\
n=81\end{array}$ & $\begin{array}{l}112,(37.6 \%) \\
n=279\end{array}$ & $\begin{array}{l}101,(53.2 \%) \\
n=190\end{array}$ \\
\hline HCV-PCR positive & $\begin{array}{l}0,(0 \%) \\
n=114\end{array}$ & $\begin{array}{l}0,(0 \%) \\
n=82\end{array}$ & $\begin{array}{l}14,(4.7 \%) \\
n=279\end{array}$ & $\begin{array}{l}13,(6.8 \%) \\
n=190\end{array}$ \\
\hline HBs-Ag positive & $\begin{array}{l}0,(0 \%) \\
n=112\end{array}$ & $\begin{array}{l}0,(0 \%) \\
n=80\end{array}$ & $\begin{array}{l}7,(2.3 \%) \\
n=275\end{array}$ & $\begin{array}{l}6,(3.2 \%) \\
n=186\end{array}$ \\
\hline Anti-HBc positive & $\begin{array}{l}1,(0.9 \%) \\
n=112\end{array}$ & $\begin{array}{l}1,(1.3 \%) \\
n=80\end{array}$ & $\begin{array}{l}102,(34.2 \%) \\
n=268\end{array}$ & $\begin{array}{l}86,(47.3 \%) \\
n=182\end{array}$ \\
\hline
\end{tabular}

Abbreviations: HBs-Ag; hepatitis B virus surface antigen; HCV, hepatitis C virus; HCV-PCR, hepatitis C virus-polymerised chain reaction; HIV, human immunodeficiency virus. 
aim of zero bleeds for all haemophilia patients. ${ }^{15-18}$ To achieve this aim, higher trough levels were aspired which might have resulted in the increase in factor consumption. The variety of treatment regimens in our patients in 2015 and the low bleeding rate show that personalized prophylaxis results in low bleeding rates with a comparably low factor consumption. However, due to the lack of individual data from 2005, we cannot exclude that other factors like an increase in BW might be the cause for the increased factor consumption, making it difficult to draw final conclusions.

Apart from this, we document a shift from the use of plasma-derived to recombinant factor concentrates. As all plasma-derived factor concentrates currently licensed in Germany are safe in terms of transmission of infections, this change is more likely due to the fact that recombinant factors are easier in handling and storage. ${ }^{19}$ In addition, switching patients from plasma-derived to recombinant factor concentrates is not related to inhibitor development in previously treated patients (PTP), ${ }^{20-22}$ which might have encouraged patients and physicians to prefer recombinant factors. Interestingly, the shift to recombinant factors is seen not only in children but also in adults. A recently published study reported a higher incidence of inhibitor development following treatment with recombinant factor concentrates in previously untreatetd patients (PUPs). ${ }^{23}$ It will be interesting to see how these data will influence the factor use especially in children in the future.

The prevalence of obesity in our patients was $8 \%$ in children and $10 \%$ in adults. Other studies reveal a much higher prevalence in other cohorts. ${ }^{24}$ As fatty tissue has lower blood volume, PWHs with obesity have an increased in vivo recovery when dosed per BW, resulting in higher trough levels. ${ }^{25-27}$ Our data reveal lower factor consumption in obese children with haemophilia when calculated per BW without an increased bleeding tendency. The same effect is seen in adults without reaching statistical significance. The reason for this finding might be the fact that physicians rather treat patients according to their bleeding tendency and trough levels than with a fixed dose per BW. When interpreting these data, it has to be taken into account that obese patients tend to have less physical activity that might lead to a lower bleeding rate as well. However, another study in adult patients with HA obese patients showed identical bleeding rates and factor consumption per BW compared with non-obese patients. ${ }^{27}$

Our data show a comparably low inhibitor rate of approximately $10 \%$ in children and even lower in adults. The reasons for the low inhibitor rate might be the high amount of patients being treated with plasma-derived factor concentrates which are known to be associated with a lower inhibitor risk in PUPs. ${ }^{23}$

Our data regarding infections are very encouraging. No child with haemophilia had an active infection with HCV, HBV or HIV. Already in 2005 no child with haemophilia had an active infection with HCV or HIV. Moreover, in the adult cohort we were able to document a dramatic reduction in the rate of patients with active hepatitis C infection. This is clearly the effect of the progress in treatment options in the last few years.

\section{Limitations}

Our study has some limitations due to its retrospective design. Factor substitution and bleeding rates were documented by the patients. As a result real factor consumption and bleeding rates might have been higher in some patients and we cannot exclude a selection bias towards a more compliant patient population represented in this study. In addition, a high number of unclear substitutions and bleedings occurred. These might have been mild bleedings, substitutions for a bleeding aura or intensified prophylaxis for physical activities, but no final assertion can be made. To diminish this effect, only patient diaries with consistent documentation were used and the treating physicians were contacted in case of conspicuities. In addition, we compared collective data from the reports submitted to the Paul Ehrlich Institute in 2005 with individual patients' data from 2015. Therefore, we were unable to analyse changes regarding bleeding rates, treatment regimens and obesity in the last decade. Moreover, we were unable to perform a statistical analysis to compare factor consumption between 2005 and 2015.

\section{Summary and Conclusion}

Comparing data from 2005 with 2015, more PWSHs in the eastern part of Germany received a prophylactic factor substitution, resulting in a moderate increase in factor consumption and low bleeding rates. More patients were treated with recombinant factor concentrates in 2015. Between 2005 and 2015, most PWHs with active HCV infections were successfully treated.

\section{Funding}

The study was supported by an unrestricted grant from Bayer HealthCare.

\section{Conflict of Interest}

Adj. Prof. Dr. J. Koscielny declares the following conflicts of interest: speaker honoraria from Aspen, Bayer Health Care Pharmaceuticals, Daiichi Sankyo, Boehringer Ingelheim, CSL Behring, Sanofi-Aventis, Shire, Roche, Chugai, Pfizer, BMS, Mitsubishi Pharma, Ferring GmbH, Sanofi-Aventis and Novo Nordisk. Adj. Prof. Dr. J. Koscielny is also a medical advisor for CSL Behring International, Bayer HealthCare Pharmaceuticals (national and international), Chugai, Roche, Shire (national) and Novo Nordisk (national) during the last 3 years. Dr. Halm-Heinrich reports personal fees and non-financial support from Novo Nordisk Deutschland, non-financial support from CSL Behring Deutschland, non-financial support from Shire Deutschland Gmbh, non-financial support from Bayer Vital $\mathrm{GmbH}$, non-financial support from Biotest AG, non-financial support from LFB GmbH, outside the submitted work. Dr. Klamroth reports grants and personal fees from Bayer, grants and personal fees from CSL Behring, grants and personal fees from Roche, grants and personal fees from Pfizer, grants and personal fees from Biomarin, grants and 
personal fees from Takeda/Shire, grants and personal fees from Novo Nordisk, grants and personal fees from SOBI, outside the submitted work. Dr. Schilling reports nonfinancial support from Bayer Vital $\mathrm{GmbH}$, personal fees from LEO Pharma $\mathrm{GmbH}$, personal fees from Novo Nordisk Pharma GmbH, personal fees from Swedish Orphan Biovitrum $\mathrm{GmbH}$, non-financial support from Roche Pharma AG, outside the submitted work. Prof. Knöfler reports grants and lecture honorarium from Bayer Vital $\mathrm{GmbH}$, Novo Nordisk GmbH, Shire Deutschland GmbH, CSL Behring $\mathrm{GmbH}$, Intersero $\mathrm{GmbH}$, Biotest AG and Swedish Orphan Biovitrum $\mathrm{GmbH}$ during the 36 months prior to publication. Dr. Tregel reports other from Grifols, grants from Octapharma, other from Shire, outside the submitted work. Dr. Pfrepper reports and Dr. C. Pfrepper declares the following conflicts of interest: speaker honoraria from BMS, Pfizer, Roche, Shire and CSL Behring. Dr. C. Pfrepper is also a medical advisor for CSL Behring, Bayer HealthCare, Roche, Chugai, Shire, Novo Nordisk and Pfizer during the last 3 years.

\section{References}

1 Srivastava A, Brewer AK, Mauser-Bunschoten EP, et al; Treatment Guidelines Working Group on Behalf of The World Federation of Hemophilia. Guidelines for the management of hemophilia. Haemophilia 2013;19(01):e1-e47

2 den Uijl I, Biesma D, Grobbee D, Fischer K. Outcome in moderate haemophilia. Blood Transfus 2014;12(Suppl 1):s330-s336

3 Manco-Johnson MJ, Abshire TC, Shapiro AD, et al. Prophylaxis versus episodic treatment to prevent joint disease in boys with severe hemophilia. N Engl J Med 2007;357(06):535-544

4 Tagliaferri A, Feola G, Molinari AC, et al; POTTER Study Group. Benefits of prophylaxis versus on-demand treatment in adolescents and adults with severe haemophilia A: the POTTER study. Thromb Haemost 2015;114(01):35-45

5 Manco-Johnson MJ, Lundin B, Funk S, et al. Effect of late prophylaxis in hemophilia on joint status: a randomized trial. JThromb Haemost 2017;15(11):2115-2124

6 Nijdam A, Foppen W, van der Schouw YT, Mauser-Bunschoten EP, Schutgens REG, Fischer K. Long-term effects of joint bleeding before starting prophylaxis in severe haemophilia. Haemophilia 2016;22(06):852-858

7 Hesse J. deutsches-haemophilieregister-dhr-patientenzahlen. Available at: https://www.pei.de/SharedDocs/Downloads/blut/dhr-deutsc hes-haemophilieregister/deutsches-haemophilieregister-dhr-patient enzahlen.pdf?_blob $=$ publicationFile $\& \mathrm{v}=54$. Accessed January 16 , 2019

8 Scholz U, Syrbe G, Koscielny J, Klamroth R; Kompetenznetzwerk Hämorrhagische Diathesen Ost (KHDO). Patienten mit Hämophilie A, B oder von-Willebrand-Syndrom Typ 3. Systematische Erfassung im Osten Deutschlands. Hamostaseologie 2008;28(03):150-154

9 Blanchette VS, Key NS, Ljung LR, Manco-Johnson MJ, van den Berg HM, Srivastava A; Subcommittee on Factor VIII, Factor IX and Rare Coagulation Disorders of the Scientific and Standardization Committee of the International Society on Thrombosis and Hemostasis. Definitions in hemophilia: communication from the SSC of the ISTH. J Thromb Haemost 2014;12(11):1935-1939

10 World Health Organization. Obesity and overweight. Available at: http://www.who.int/news-room/fact-sheets/detail/obesity-and- overweight. Updated February 16, 2018. Accessed November 14, 2018

11 Kromeyer-Hauschild K, Wabitsch M, Kunze D, et al. Perzentile für den Body-mass-Index für das Kindes- und Jugendalter unter Heranziehung verschiedener deutscher Stichproben. Monatsschr Kinderheilkd 2001;149(08):807-818

12 Moss A, Wabitsch M, Kromeyer-Hauschild K, Reinehr T, Kurth BM. Prävalenz von Ubergewicht und Adipositas bei deutschen Einschulkindern. Bundesgesundheitsblatt Gesundheitsforschung Gesundheitsschutz 2007;50(11):1424-1431

13 Olivieri M, Königs C, Heller C, et al. Prevalence of obesity in young patients with severe haemophilia and its potential impact on factor VIII consumption in Germany. Hamostaseologie 2019 (epub ahead of print) . Doi: 10.1055/s-0039-1677874

14 Chen CX, Baker JR, Nichol MB. Economic burden of illness among persons with hemophilia B from HUGS Vb: examining the association of severity and treatment regimens with costs and annual bleed rates. Value Health 2017;20(08):1074-1082

15 Collins PW. Personalized prophylaxis. Haemophilia 2012;18 (Suppl 4):131-135

16 Jiménez-Yuste V, Auerswald G, Benson G, et al. Achieving and maintaining an optimal trough level for prophylaxis in haemophilia: the past, the present and the future. Blood Transfus 2014;12(03):314-319

17 Herbert RD, Broderick CR, Barnes C, Billot L, Zhou A, Latimer J. Optimization of prophylaxis for hemophilia A. PLoS One 2018;13 (02): $\mathrm{e} 0192783$

18 Iorio A, Edginton AN, Blanchette V, et al. Performing and interpreting individual pharmacokinetic profiles in patients with Hemophilia A or B: rationale and general considerations. Res Pract Thromb Haemost 2018;2(03):535-548

19 Tischer B, Marino R, Napolitano M. Patient preferences in the treatment of hemophilia A: impact of storage conditions on product choice. Patient Prefer Adherence 2018;12:431-441

20 Giles AR, Rivard GE, Teitel J, Walker I. Surveillance for factor VIII inhibitor development in the Canadian Hemophilia A population following the widespread introduction of recombinant factor VIII replacement therapy. Transfus Sci 1998;19(02):139-148

21 Bacon CL, Singleton E, Brady B, et al. Low risk of inhibitor formation in haemophilia A patients following en masse switch in treatment to a third generation full length plasma and albumin-free recombinant factor VIII product (ADVATE®). Haemophilia 2011;17(03):407-411

22 Santagostino E, Auerswald G, Benson G, et al. Switching treatments in haemophilia: is there a risk of inhibitor development? Eur J Haematol 2015;94(04):284-289

23 Peyvandi F, Mannucci PM, Garagiola I, et al. A randomized trial of factor VIII and neutralizing antibodies in hemophilia A. N Engl J Med 2016;374(21):2054-2064

24 Kahan S, Cuker A, Kushner RF, et al. Prevalence and impact of obesity in people with haemophilia: review of literature and expert discussion around implementing weight management guidelines. Haemophilia 2017;23(06):812-820

25 Henrard S, Speybroeck N, Hermans C. Body weight and fat mass index as strong predictors of factor VIII in vivo recovery in adults with hemophilia A. JThromb Haemost 2011;9(09):1784-1790

26 Blanchette VS, Shapiro AD, Liesner RJ, et al; rAHF-PFM Clinical Study Group. Plasma and albumin-free recombinant factor VIII: pharmacokinetics, efficacy and safety in previously treated pediatric patients. J Thromb Haemost 2008;6(08):1319-1326

27 Tuinenburg A, Biere-Rafi S, Peters M, et al. Obesity in haemophilia patients: effect on bleeding frequency, clotting factor concentrate usage, and haemostatic and fibrinolytic parameters. Haemophilia 2013;19(05):744-752 